\title{
Theoretical and numerical analysis of reinforced concrete beams with confinement reinforcement
}

\section{Análise teórica e experimental de vigas de concreto armado com armadura de confinamento}
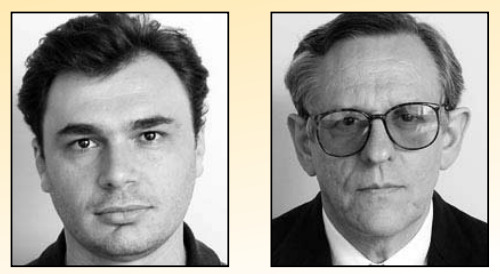

R. G. DELALIBERA dellacivil@gmail.com

J. S. GIONGO' jsgiongo@sc.usp.br

\begin{abstract}
This paper discusses the use of confinement in over-reinforced concrete beams. This reinforcement consists of square stirrups, placed in the compression zone of the beam cross-section, in order to improve its ductility. A parametric numerical study is initially performed, using a finite element computational program that considers the material nonlinearities and the confinement effect. To investigate the influence of the transverse reinforcing ratio on the beam ductility, an experimental program was also conducted. Four over-reinforced beams were tested; three beam specimens with additional transverse reinforcement to confine the beams, and one without it. All specimens were fabricated with a concrete designed for a compressive strength of $25 \mathrm{MPa}$. The experimental results show that the post-peak ductility factor is proportional to the confining reinforcement ratio, however the same is not observed for the pre-peak ductility factor, which varied randomly with changes in the confining reinforcement ratio. It was also observed from the experiments that the confinement effect tends to be smaller close to the beam neutral axis.
\end{abstract}

Keywords: beams; confinement reinforcement; ductility.

\section{Resumo}

Este trabalho discute a utilização de armadura de confinamento em vigas superarmadas de concreto armado. Essa armadura é constituída de estribos quadrados colocados na região de compressão da seção transversal da viga, aumentando a ductilidade. Para a análise numérica, utilizou-se um programa computacional baseado no Método dos Elementos Finitos que considera o efeito do confinamento no concreto, possibilitando estudar criteriosamente a influência da armadura de confinamento em vigas superarmadas. Na etapa experimental foi investigada a influência da taxa volumétrica da armadura transversal de confinamento, sendo realizados ensaios de quatro vigas superarmadas - três detalhadas com estribos adicionais destinados ao confinamento e uma projetada sem armadura de confinamento. Todas as vigas tiveram deformações nas barras da armadura de tração próximas a $\varepsilon_{\mathrm{y}}$ e resistência média à compressão do concreto de $25 \mathrm{MPa}$. Os resultados experimentais mostraram que o índice de ductilidade pós-pico é proporcional à taxa volumétrica da armadura transversal de confinamento. Isso não aconteceu para o índice de ductilidade pré-pico, que teve variação aleatória com a taxa volumétrica de armadura de confinamento. Observou-se também que a resistência à compressão do concreto confinado no núcleo de confinamento diminuiu na proximidade da linha neutra.

Palavras-chave: vigas; armadura de confinamento; ductilidade; concreto armado.

a Department of Structural Engineering, São Carlos Engineering School, São Paulo University, dellacivil@gmail.com, Av. Trabalhador Sãocarlense, 400, CEP: 13566-590, São Carlos - SP, Brasil;

${ }^{b}$ Department of Structural Engineering, São Carlos Engineering School, São Paulo University, jsgiongo@sc.usp.br, Av. Trabalhador Sãocarlense, 400, CEP: 13566-590, São Carlos - SP, Brasil. 


\section{Introduction}

The ductility analysis of reinforced concrete beams has been studied by several researchers, Base [1], Base \& Read [2], Nawy [3] and Ziara et al. [4]. In this paper over-reinforced concrete beams were theoretically and experimentally analyzed. These beams (see Figure [1]) had a confinement reinforcement configuration and concrete compression strength of $25 \mathrm{MPa}$ after 25 days in order to observe the influence of the confinement reinforcement on the structural behavior of the beams.

A computational program based on the Finite Element Method, which considers the physical and geometrical non-linearity of the structure as well as the effect of the confinement stirrups, carried out the theoretical analysis.

The computational program was developed by Krüger [5] while the implementation of the confinement model was developed by Lima Júnior \& Giongo [6]. The confinement model used in the program was created by Saatcioglu \& Razvi [7]. The methodology, developed by Lima Júnior \& Giongo [8], was used to determine and calculate the ductility indexes of the numerically and experimentally analyzed reinforced concrete beams.

Therefore, a statistics plan was created to determine the ideal ductility indexes, considering normally balanced beams. These indexes were determined by numerically analyzing underreinforced beams with $10 \%$ longitudinal strain in the tensile reinforcement and $3.5 \%$ concrete longitudinal strain (compressive zone), varying the height and width of the beam cross section as well as the concrete compression strength. Over-reinforced beams with confinement reinforcement were also numerically analyzed. An analysis of variance was createdwith the ductility indexes of each over-reinforced beam to verify which variables are more rel- evant in the ductility study. The variance analysis comprised the following variables : the concrete compression strength, the tensile reinforcement strain, confinement reinforcement spacing and the geometrical shape of the stirrups used for confinement.

Considering the results obtained through the numerical analysis along with an understanding acquired through bibliographic review, an experimental program was elaborated with the aim to analyze the ductility of the beams with confinement reinforcement. This program consisted of testing four reinforced concrete beams, whereas three of them were designed with confinement reinforcement and one without it. All the tested beams were designed following normally balanced beams specifications considering the specific concrete strains equal to $3.5 \%$, in the compressive zone.

\section{Validation of the computational model}

A comparative analysis based on the experimental results from several authors was carried out to verify if the numerical model which was used provides good results.

In 1962, Base [1] tested 2 reinforced concrete beams, whereas one was designed in a conventional way and the second with helical confinement reinforcement placed in the compression zone of the beam cross section. A good approximation between the models was observed with a $0.70 \%$ difference between the found maximum loads. In the experimental model the displacement measured at mid-span, when the tensile reinforcement yielding started, was $1.05 \mathrm{~cm}$, while the numerical model had a strain of $1.89 \mathrm{~cm}$, presenting therefore a difference of $56 \%$ between the two models. In 1965, Base \& Read [2] also carried out an experimental analysis with sixteen reinforced concrete beams, whereby six were designed with helical confinement reinforcement also placed in the compres-

Table 1 - Difference between the experimental and numerical models, Base \& Read (2)

\begin{tabular}{cccc|} 
Beams & $\begin{array}{c}\text { Maximum load }-F_{\max }(\mathrm{kN}) \\
\text { Experimental }\end{array}$ & $\begin{array}{c}\text { Difíference } \\
(\%)\end{array}$ \\
\hline 1 & 58.8 & 51.1 & 15.0 \\
2 & 56.1 & 52.5 & 6.5 \\
4 & 112.3 & 108.6 & 3.3 \\
5 & 112.1 & 104.9 & 6.5 \\
9 & 149.8 & 165.0 & 9.3 \\
16 & 226.4 & 171.5 & 24.3 \\
\hline
\end{tabular}


Table 2 - Difference between the experimental and numerical models, Nawy et al. (3)

\begin{tabular}{|cccc|} 
Beams & $\begin{array}{r}\text { Maximum Moment }-\mathbf{M}_{\max }(\mathrm{kNcm}) \\
\text { Experimental }\end{array}$ & $\begin{array}{c}\text { Difference } \\
\text { Numerical }\end{array}$ \\
P10G2 & 21920.9 & 25657.1 & 14.6 \\
P11G3 & 19550.9 & 18840.6 & 3.6 \\
P14G6 & 19632.1 & 18985.1 & 3.2 \\
P5G7 & 24913.1 & 25918.8 & 3.9 \\
P6G8 & 21714.2 & 25871.2 & 16.1 \\
B8B4 & 4022.3 & 3536.6 & 9.5 \\
B12B6 & 3722.4 & 3731.5 & 0.2 \\
B5B8 & 3803.1 & 3748. & 1.5 \\
B2B10 & 5106.9 & 4656.3 & 8.8 \\
B11B12 & 3371.3 & 3801.1 & 11.3 \\
\hline
\end{tabular}

sion zones of the cross sections. From these 6 confined beams, 2 were under-reinforced beams (beams 1 and 2), two were normally reinforced (beams 4 and 5) and two were beams (beams 9 and 16). It was observed that the computational model presented a satisfactory behavior. In beam 16 a great discrepancy between the results was noticed and the authors could not identify the possible causes for this fact. Table [1] presents the differences found between the theoretical and experimental results.

Nawy et al. [3] tested two series of beams confined with continuous rectangular helical reinforcement to verify the plastic rotation capacity of the beams. The confinement stirrups of these beams covered the whole cross section, deducting the concrete cover, therefore similar to the stirrups used for the shear stress. This stirrup arrangement is not as effective as the arrangement in just the compression zone of the cross section, because parts of the stirrups are located in the tensile zone of the beam causing deficiency in the confinement. In Table [2], the results obtained by compar- ing the theoretical and experimental model are presented. It was observed that the numerical model was not as effective as the analyses carried out before. One of the factors might have been the presence of tensile stresses in the confinement stirrups, because these stirrups enveloped the whole cross section deducting the concrete cover. However, it was observed, that the maximum bending moments obtained numerically had a good approximation compared to those obtained in the experiments.

Ziara et al. [4] tested two series of reinforced concrete beams confined through rectangular stirrups, whereby one series with under-reinforced beams and the other with beams. For the underreinforced beams, the confinement stirrups were placed just in the compression zone of the beam cross section, while for the beams the confinement stirrups were placed around the whole cross section, deducting the concrete cover. As the confinement stirrups are similar to the stirrups used for shear stress, this may cause inefficiency in the confinement as mentioned before.

Table 3 - Difference between the experimental and numerical model, Ziara et al. (4)

\begin{tabular}{|c|c|c|c|}
\hline \multirow{2}{*}{ Beams } & \multicolumn{2}{|c|}{ Maximum load - $F_{\max }(k N)$} & \multirow{2}{*}{$\begin{array}{c}\text { Difference } \\
(\%)\end{array}$} \\
\hline & Experimental & Numerical & \\
\hline NA2-1 & 435 & 496.7 & 12.4 \\
\hline NA3-1 & 430 & 510.4 & 15.7 \\
\hline NB2-1 & 255 & 266.6 & 4.3 \\
\hline NB3-1 & 251 & 280.7 & 10.6 \\
\hline $\mathrm{C} 2$ & 489.3 & 446.7 & 9.6 \\
\hline C3-2 & 216.1 & 149.5 & 30.8 \\
\hline
\end{tabular}


Table 4 - General properties of beams, with c=3.5\%० and s=10\%。, IDideal, Delalibera (9)

\begin{tabular}{|c|c|c|c|c|c|c|c|c|c|c|c|c|c|}
\hline Beams & $\begin{array}{c}f_{c k} \\
(M P a)\end{array}$ & $\begin{array}{l}\mathrm{b}_{\mathrm{w}} \\
(\mathrm{cm})\end{array}$ & $\begin{array}{c}d \\
(\mathrm{~cm})\end{array}$ & $\begin{array}{c}\mathrm{h} \\
(\mathrm{cm})\end{array}$ & $\begin{array}{c}A_{s} \\
\left(\mathrm{~cm}^{2}\right)\end{array}$ & $\begin{array}{c}A_{s, \text { adopted }} \\
\emptyset \\
(\mathrm{mm})\end{array}$ & $\begin{array}{l}\text { Amount } \\
\text { (un.) }\end{array}$ & $\begin{array}{l}d_{c 0, i y} \\
(\mathrm{~cm})\end{array}$ & $\begin{array}{l}F_{\max } \\
(k N)\end{array}$ & $\begin{array}{c}\mathbb{R}_{\mathrm{c}} \\
(\mathrm{kN} / \mathrm{cm})\end{array}$ & $\mathrm{ID}_{\text {pre }}$ & $\mathbf{I D}_{\text {post }}$ & ID $_{\text {elast. }}$ \\
\hline V201020 & 20 & 10 & 17 & 20 & 0.4 & 5.0 & 2 & 1.52 & 5.0 & 31.50 & 0.499 & 0.914 & 0.105 \\
\hline V201060 & 20 & 10 & 56 & 60 & 1.0 & 8.0 & 2 & 0.45 & 40.3 & 626.20 & 0.495 & 0.915 & 0.143 \\
\hline V201010 & 20 & 10 & 95 & 100 & 1.6 & 10.0 & 2 & 0.27 & 109.2 & 1795.81 & 0.477 & 0.894 & 0.255 \\
\hline V203020 & 20 & 30 & 17 & 20 & 1.0 & 8.0 & 2 & 1.40 & 11.0 & 96.27 & 0.609 & 0.915 & 0.082 \\
\hline V203060 & 20 & 30 & 56 & 60 & 3.0 & $\begin{array}{l}12.5 \\
8.0\end{array}$ & $\begin{array}{l}2 \\
1\end{array}$ & 0.45 & 120.9 & 1804.68 & 0.508 & 0.878 & 0.149 \\
\hline V203010 & 20 & 30 & 95 & 100 & 5.0 & 25.0 & 2 & 0.27 & 338.6 & 5344.55 & 0.411 & 0.910 & 0.235 \\
\hline V205020 & 20 & 50 & 17 & 20 & 1.6 & 10.0 & 2 & 1.56 & 19.9 & 155.73 & 0.572 & 0.863 & 0.082 \\
\hline V205060 & 20 & 50 & 56 & 60 & 4.8 & $\begin{array}{l}16.0 \\
10.0\end{array}$ & $\begin{array}{l}2 \\
1\end{array}$ & 0.47 & 192.5 & 3777.99 & 0.569 & 0.886 & 0.108 \\
\hline V205010 & 20 & 50 & 97 & 100 & 8.3 & $\begin{array}{l}20.0 \\
16.0\end{array}$ & $\begin{array}{l}2 \\
1\end{array}$ & 0.27 & 562.9 & 8669.95 & 0.413 & 0.902 & 0.240 \\
\hline V351020 & 35 & 10 & 17 & 20 & 0.5 & 8.0 & 2 & 1.54 & 6.3 & 38.17 & 0.517 & 0.879 & 0.108 \\
\hline V351060 & 35 & 10 & 56 & 60 & 1.5 & 8.0 & 3 & 0.46 & 60.6 & 963.91 & 0.495 & 0.881 & 0.137 \\
\hline V351010 & 35 & 10 & 95 & 100 & 2.5 & 12.5 & 2 & 0.27 & 170.9 & 2483.17 & 0.382 & 0.880 & 0.255 \\
\hline V353020 & 35 & 30 & 17 & 20 & 1.6 & 10.0 & 2 & 1.55 & 20.0 & 113.90 & 0.490 & 0.886 & 0.113 \\
\hline V353060 & 35 & 30 & 5 & 60 & 5.3 & $\begin{array}{l}16.0 \\
12.5\end{array}$ & $\begin{array}{l}2 \\
1\end{array}$ & 0.50 & 209.9 & 2871.08 & 0.473 & 0.915 & 0.146 \\
\hline V353010 & 35 & 30 & 95 & 100 & 10.0 & 25.0 & 2 & 0.29 & 679.2 & 8210.52 & 0.295 & 0.924 & 0.285 \\
\hline V355020 & 35 & 50 & 17 & 20 & 2.5 & 12.5 & 2 & 1.52 & 31.5 & 213.47 & 0.641 & 0.895 & 0.097 \\
\hline V355060 & 35 & 50 & 56 & 60 & 8.3 & $\begin{array}{l}20.0 \\
16.0\end{array}$ & $\begin{array}{l}2 \\
1\end{array}$ & 0.49 & 331.5 & 4899.90 & 0.471 & 0.905 & 0.138 \\
\hline V355010 & 35 & 50 & 95 & 100 & 15.0 & 25.0 & 3 & 0.29 & 1013.3 & 12914.30 & 0.327 & 0.912 & 0.271 \\
\hline V501020 & 50 & 10 & 17 & 20 & 0.8 & 10.0 & 2 & 1.64 & 9.9 & 43.31 & 0.430 & 0.913 & 0.140 \\
\hline V501060 & 50 & 10 & 56 & 60 & 2.5 & 12.5 & 2 & 0.50 & 100.2 & 1133.30 & 0.397 & 0.911 & 0.177 \\
\hline V501010 & 50 & 10 & 95 & 100 & 4.0 & 16.0 & 2 & 0.30 & 272.3 & 5502.05 & 0.499 & 0.922 & 0.167 \\
\hline V503020 & 50 & 30 & 17 & 20 & 2.5 & 12.5 & 2 & 1.61 & 30.6 & 113.88 & 0.413 & 0.943 & 0.167 \\
\hline V503060 & 50 & 30 & 56 & 60 & 7.1 & $\begin{array}{l}20.0 \\
10.0\end{array}$ & $\begin{array}{l}2 \\
1\end{array}$ & 0.50 & 283.4 & 3327.15 & 0.488 & 0.927 & 0.170 \\
\hline V503010 & 50 & 30 & 95 & 10 & 12.0 & $\begin{array}{l}25.0 \\
16.0\end{array}$ & $\begin{array}{l}2 \\
1\end{array}$ & 0.30 & 811.8 & 9016.50 & 0.285 & 0.916 & 0.303 \\
\hline V505020 & 50 & 50 & 17 & 20 & 4.0 & 16.0 & 2 & 1.67 & 48.8 & 215.96 & 0.439 & 0.915 & 0.135 \\
\hline V505060 & 50 & 50 & 56 & 60 & 12.0 & $\begin{array}{l}25.0 \\
16.0\end{array}$ & $\begin{array}{l}2 \\
1\end{array}$ & 0.50 & 476.7 & 5685.64 & 0.408 & 0.914 & 0.168 \\
\hline V505010 & 50 & 50 & 95 & 100 & 21.0 & $\begin{array}{l}32.0 \\
25.0\end{array}$ & $\begin{array}{l}2 \\
1\end{array}$ & 0.30 & 1413.0 & 16411.70 & 0.282 & 0.927 & 0.287 \\
\hline
\end{tabular}


Table 5 - General properties of beams confined through square stirrups, Delalibera (9)

\begin{tabular}{|c|c|c|c|c|c|c|c|c|c|c|c|c|}
\hline \multirow[b]{2}{*}{ Beams } & \multirow[b]{2}{*}{$\begin{array}{c}b_{w} \\
(\mathrm{~cm})\end{array}$} & \multirow[b]{2}{*}{$\begin{array}{c}\mathrm{h} \\
(\mathrm{cm})\end{array}$} & \multirow[b]{2}{*}{$\begin{array}{c}d \\
(\mathrm{~cm})\end{array}$} & \multicolumn{3}{|c|}{ Asw,conf. } & \multirow[b]{2}{*}{$\begin{array}{c}f_{\mathrm{ck}} \\
(\mathrm{MPa})\end{array}$} & \multirow[b]{2}{*}{$\begin{array}{c}\varepsilon_{\mathrm{s}} \\
(\% \circ)\end{array}$} & \multirow[b]{2}{*}{$\begin{array}{c}A_{\mathrm{st}} \\
\left(\mathrm{cm}^{2}\right)\end{array}$} & \multicolumn{3}{|c|}{ Confinement } \\
\hline & & & & $\begin{array}{l}h_{c}=d_{c} \\
(\mathrm{~cm})\end{array}$ & $\begin{array}{c}\mathrm{s} \\
(\mathrm{cm})\end{array}$ & $\begin{array}{c}\emptyset \\
(\mathrm{mm})\end{array}$ & & & & $\begin{array}{c}f_{c c} \\
(M P a)\end{array}$ & $\begin{array}{c}\varepsilon_{\mathrm{c}} \\
(\% \circ)\end{array}$ & $\begin{array}{l}\varepsilon_{\mathrm{c} 85} \\
(\% \circ)\end{array}$ \\
\hline VF201512R & 10 & 30 & 27 & 7.5 & 12 & 5.00 & 20 & 1.5 & 6.53 & 22.56 & 3.258 & 7.496 \\
\hline VF201575R & 10 & 30 & 27 & 7.5 & 7,5 & 5.00 & 20 & 1.5 & 6.53 & 23.79 & 3.865 & 10.82 \\
\hline VF201530R & 10 & 30 & 27 & 7.5 & 3 & 5.00 & 20 & 1.5 & 6.53 & 25.30 & 4.617 & 16.37 \\
\hline VF201012R & 10 & 30 & 27 & 7.5 & 12 & 5.00 & 20 & 1.0 & 10.88 & 22.56 & 3.258 & 7.496 \\
\hline VF201075R & 10 & 30 & 27 & 7.5 & 7,5 & 5.00 & 20 & 1.0 & 10.88 & 23.79 & 3.865 & 10.82 \\
\hline VF201030R & 10 & 30 & 27 & 7.5 & 3 & 5.00 & 20 & 1.0 & 10.88 & 25.30 & 4.617 & 16.37 \\
\hline VF200512R & 10 & 30 & 27 & 7.5 & 12 & 5.00 & 20 & 0.5 & 24.48 & 22.56 & 3.258 & 7.496 \\
\hline VF200575R & 10 & 30 & 27 & 7.5 & 7,5 & 5.00 & 20 & 0.5 & 24.48 & 23.79 & 3.865 & 10.82 \\
\hline VF200530R & 10 & 30 & 27 & 7.5 & 3 & 5.00 & 20 & 0.5 & 24.48 & 25.30 & 4.617 & 16.37 \\
\hline VF351512R & 10 & 30 & 27 & 7.5 & 12 & 5.00 & 35 & 1.5 & 11.42 & 37.56 & 3.005 & 7.209 \\
\hline VF351575R & 10 & 30 & 27 & 7.5 & 7,5 & 5.00 & 35 & 1.5 & 11.42 & 38.79 & 3.980 & 9.953 \\
\hline VF351530R & 10 & 30 & 27 & 7.5 & 3 & 5.00 & 35 & 1.5 & 11.42 & 43.10 & 4.746 & 25.34 \\
\hline VF351012R & 10 & 30 & 27 & 7.5 & 12 & 5.00 & 35 & 1.0 & 19.04 & 37.56 & 3.005 & 7.209 \\
\hline VF351075R & 10 & 30 & 27 & 7.5 & 7,5 & 5.00 & 35 & 1.0 & 19.04 & 38.79 & 3.980 & 9.953 \\
\hline VF351030R & 10 & 30 & 27 & 7.5 & 3 & 5.00 & 35 & 1.0 & 19.04 & 43.10 & 4.746 & 25.34 \\
\hline VF350512R & 10 & 30 & 27 & 7.5 & 12 & 5.00 & 35 & 0.5 & 42.40 & 37.56 & 3.005 & 7.209 \\
\hline VF350575R & 10 & 30 & 27 & 7.5 & 7,5 & 5.00 & 35 & 0.5 & 42.40 & 38.79 & 3.980 & 9.953 \\
\hline VF350530R & 10 & 30 & 27 & 7.5 & 3 & 5.00 & 35 & 0.5 & 42.40 & 43.10 & 4.746 & 25.34 \\
\hline VF501512R & 10 & 30 & 27 & 7.5 & 12 & 5.00 & 50 & 1.5 & 16.32 & 52.56 & 3.033 & 7.241 \\
\hline VF501575R & 10 & 30 & 27 & 7.5 & 7,5 & 5.00 & 50 & 1.5 & 16.32 & 53.78 & 3.328 & 9,842 \\
\hline VF501530R & 10 & 30 & 27 & 7.5 & 3 & 5.00 & 50 & 1.5 & 16.32 & 58.10 & 4.371 & 23.63 \\
\hline VF501012R & 10 & 30 & 27 & 7.5 & 12 & 5.00 & 50 & 1.0 & 27.20 & 52.56 & 3.033 & 7.241 \\
\hline VF501075R & 10 & 30 & 27 & 7.5 & 7,5 & 5.00 & 50 & 1.0 & 27.20 & 53.78 & 3.328 & 9.842 \\
\hline VF501030R & 10 & 30 & 27 & 7.5 & 3 & 5.00 & 50 & 1.0 & 27.20 & 58.10 & 4.371 & 23.63 \\
\hline VF500512R & 10 & 30 & 27 & 7.5 & 12 & 5.00 & 50 & 0.5 & 61.20 & 52.56 & 3.033 & 7.241 \\
\hline VF500575R & 10 & 30 & 27 & 7.5 & 7,5 & 5.00 & 50 & 0.5 & 61.20 & 53.78 & 3.328 & 9.842 \\
\hline VF500530R & 10 & 30 & 27 & 7.5 & 3 & 5.00 & 50 & 0.5 & 61.20 & 58.10 & 4.371 & 23.63 \\
\hline VF20 & 10 & 30 & 27 & - & - & - & 20 & 2.38 & 4.37 & - & - & - \\
\hline VF35 & 10 & 30 & 27 & - & - & - & 35 & 2.38 & 8.08 & - & - & - \\
\hline VF50 & 10 & 30 & 27 & - & - & - & 50 & 2.38 & 11.54 & - & - & - \\
\hline
\end{tabular}


In Table [3] it is possible to observe the differences between the theoretical and experimental models. The numerical model presents good approximation with an excessive difference in just one of the analyzed beams probably by the fact that the confinement stirrups enveloped the whole cross section of the beam.

With the twenty-three beams simulated numerically, it was possible to observe that the numerical model provided good results and consistency, although some beams presented great differences compared with the experimental models. Delalibera [9] presents more details about the numerical simulation.

\section{Determination of the ideal ductility Index}

To determine an ideal index for the beams, a statistical study was carried out with 27 under-reinforced beams designed with strain in the tensile reinforcement equal to $10 \%$ and in the concrete equal to $3.5 \%$, that is, beams with strains related to down balanced beams specifications, according to the Brazilian Standard NBR 6118:2003 [10]. The beams were supported and had a theoretical span of $300 \mathrm{~cm}$.

These beams were chosen to determine the ideal ductility index, because their structural behavior follows the stress vs. strain diagram of the tensile reinforcement. The steel yields until the strain of $10 \%$ before the concrete reaches the strain limit for the ultimate limit state. The beams were numerically analyzed using the numerical model as mentioned previously.

Based on the non-linearity of the problem, three study parameters were chosen for the involved variables. In Table [4], the general properties of the numerically analyzed beams are presented.

A statistical study was carried out with the data of Table 4 . The ideal pre-peak ductility index (ID $\left.\mathrm{Dre}_{\text {pideal }}\right)$ of 0.455 and the ideal post-peak ductility index ( $\left.I \mathrm{D}_{\text {post.ideal }}\right)$ of 0.905 were found. These values were obtained through the average of the ductility indexes of the analyzed beams, whereby the standard deviations for the ideal pre-peak and post-peak ductility indexes were 0.092 and 0.0188 respectively.

Where $f_{c k}$ is the characteristic compression strength of the concrete, $b_{w}$ the width of the beam cross section, $h$ the height of the cross section, $d$ the effective height of the beam, $A_{s}$ the area of the tensile reinforcement, $\varnothing$ the diameter of the tensile reinforcement, $\delta_{c 0, f y}$ strain at the yielding moment of the tensile reinforcement, $\mathrm{F}_{\max }^{\mathrm{co} \text { fy }}$ the maximum load supported by the beam, $I R_{c}$ the stiffness index of the beam, $I D_{\text {pre }}$ the pre-peak ductility index, $I D_{\text {post }}$ the postpeak ductility index $\mathrm{e} I \mathrm{I}_{\text {elast }}$ the elastic ductility index, the ductility indexes were calculated using the method proposed by Lima Júnior \& Giongo [11] and presented in Table [4]. The CA-50 steel (in accordance with Brazilian Standard NBR 7480:1996 [12]) was used for all the analyzed beams. Through this numerical analysis, the values of volumetric ratio of transverse confinement reinforcement used in the experimental analysis were obtained. For details, please refer to Delalibera [9].

\section{Numerical analysis}

The objective of this analysis is to evaluate the structural behavior of reinforced concrete beams designed with confinement reinforcement, which were dimensioned following overbalanced beam specifications. Therefore 27 beams confined with square stirrups were analyzed. Three reference beams are also presented (see Table [5]). These three beams were designed in a conventional way, without confinement reinforcement, with strains in the tensile reinforcement equal to $\varepsilon_{y}$. The details of the beams are presented in Figure [1]. The CA-50 steel [12] was used for both longitudinal and transversal reinforcement. The diameter of the stirrups used for confinement was $5 \mathrm{~mm}$. All the beams have a cross section of $10 \mathrm{~cm}$ width and $30 \mathrm{~cm}$ height. The general properties of the beams in study are presented in Table [5].

It is possible to observe the ductility increase and the flexural strength increase, as a consequence of the increase of the transverse confinement reinforcement ratio.

The pre-peak $\left(\mathrm{ID}_{\text {pre }}\right)$ and post-peak $\left(\mathrm{ID}_{\text {post }}\right)$ ductility indexes are presented in Table [6].

With the data of Table [6] an analysis of variance was carried out where it is possible to verify that, for the pre-peak ductility index, the most relevant variable is the characteristic concrete compression strength, followed by the tensile reinforcement strain. For the post-peak ductility index, all the variables involved had relevant influence. These data can be observed in Table [7], through the influence factor $F_{0}$.

With the data obtained through the analysis of variance and using the pre-peak and post-peak ductility indexes given in Table [7] a non-linear regression was carried out, in which the obtained expressions describe those indexes. However it is possible to confirm that the pre-peak ductility index is a function of the characteristic concrete compression strength and also of the tensile reinforcement, while the post-peak ductility index is a function of all the involved variables. The post-peak and pre-peak ductility indexes for the beams confined with square stirrups can be expressed by Equations [1] and [2].

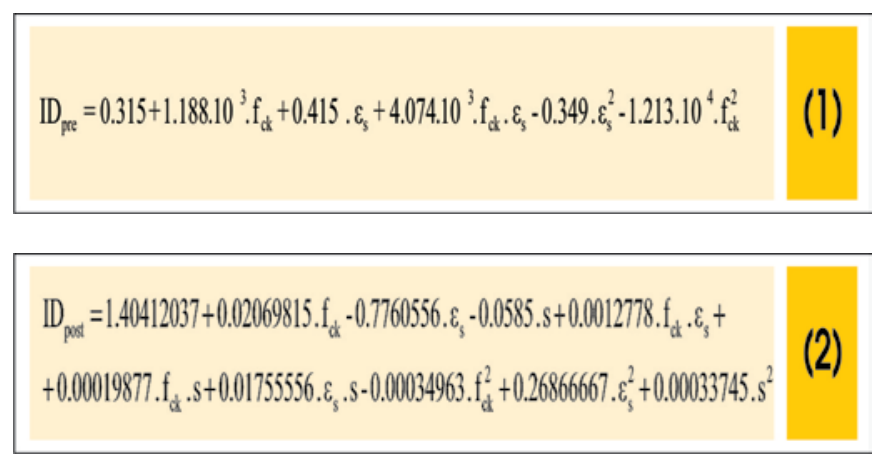


Where, $\mathrm{f}_{\mathrm{ck}}, \mathrm{s}$, and $\varepsilon_{\mathrm{s}}$ expressed in $\mathrm{MPa}, \mathrm{cm}$ and $\%$ respectively. The correlation coefficients for the regressions of the pre-peak and post-peak ductility were $95 \%$ and $77 \%$, observing that even disregarding some variables the correlation coefficients present satisfactory values.

\begin{tabular}{|c|c|c|c|c|c|c|c|c|c|}
\hline \multicolumn{10}{|c|}{ Table 6 - Ductility indexes of beams confined through square stirrups } \\
\hline Beams & $\begin{array}{l}\mathbf{F}_{\max } \\
(\mathrm{kN})\end{array}$ & $\begin{array}{l}\text { Increase } \\
\text { of beam } \\
\text { flexural } \\
\text { strength } \\
(\%)\end{array}$ & $\begin{array}{c}e_{\mathrm{s}} \\
(\% \circ)\end{array}$ & $\begin{array}{c}f_{\mathrm{ck}} \\
(\mathrm{MPa})\end{array}$ & $\begin{array}{c}\mathrm{s} \\
(\mathrm{cm})\end{array}$ & $\begin{array}{c}\delta_{\mathrm{co}} \\
(\mathrm{cm})\end{array}$ & $\mathbf{I D}_{\text {pre }}$ & $I_{\text {post }}$ & $I_{\text {elast }}$ \\
\hline VF201512R & $70.65^{*}$ & - & 1.5 & 20 & 12 & 2.304 & 0.231 & 0.903 & 0.908 \\
\hline VF201575R & 72.21 & 2.16 & 1.5 & 20 & 7.5 & 2.926 & 0.237 & 1.007 & 0.908 \\
\hline VF201530R & 73.89 & 4.39 & 1.5 & 20 & 3 & 3.805 & 0.246 & 1.023 & 0.908 \\
\hline VF201012R & $78.97^{\star}$ & - & 1.0 & 20 & 12 & 2.749 & 0.445 & 0.700 & 0.757 \\
\hline VF201075R & 85.53 & 8.18 & 1.0 & 20 & 7.5 & 3.388 & 0.468 & 0.978 & 0.757 \\
\hline VF201030R & 93.13 & 15.21 & 1.0 & 20 & 3 & 4.228 & 0.474 & 1.151 & 0.757 \\
\hline VF200512R & $82.65^{*}$ & - & 0.5 & 20 & 12 & 2.121 & 0.434 & 0.943 & 0.640 \\
\hline VF200575R & 88.76 & 6.88 & 0.5 & 20 & 7.5 & 2.592 & 0.455 & 1.033 & 0.640 \\
\hline VF200530R & 95.94 & 13.85 & 0.5 & 20 & 3 & 3.246 & 0.476 & 1.149 & 0.640 \\
\hline VF351512R & $120.48^{*}$ & - & 1.5 & 35 & 12 & 2.539 & 0.259 & 0.946 & 0.953 \\
\hline VF351575R & 122.69 & 1.80 & 1.5 & 35 & 7.5 & 2.592 & 0.263 & 0.982 & 0.953 \\
\hline VF351530R & 128.22 & 6.03 & 1.5 & 35 & 3 & 4.565 & 0.273 & 1.069 & 0.953 \\
\hline VF351012R & $130.15^{*}$ & - & 1.0 & 35 & 12 & 2.732 & 0.375 & 0.860 & 0.914 \\
\hline VF351075R & 138.01 & 5.69 & 1.0 & 35 & 7.5 & 3.249 & 0.389 & 0.940 & 0.914 \\
\hline VF351030R & 208.59 & 37.61 & 1.0 & 35 & 3 & 8.301 & 0.417 & 1.373 & 0.914 \\
\hline VF350512R & $129.13^{*}$ & - & 0.5 & 35 & 12 & 2.096 & 0.364 & 0.943 & 0.751 \\
\hline VF350575R & 143.08 & 9.75 & 0.5 & 35 & 7.5 & 2.524 & 0.404 & 1.089 & 0.751 \\
\hline VF350530R & 165.01 & 21.74 & 0.5 & 35 & 3 & 4.005 & 0.430 & 1.257 & 0.751 \\
\hline VF501512R & $169.92^{*}$ & - & 1.5 & 50 & 12 & 2.713 & 0.222 & 0.961 & 1.130 \\
\hline VF501575R & 172.89 & 1.72 & 1.5 & 50 & 7.5 & 2.640 & 0.226 & 0.971 & 1.130 \\
\hline VF501530R & 179.33 & 5.25 & 1.5 & 50 & 3 & 4.083 & 0.230 & 1.046 & 1.130 \\
\hline VF501012R & $181.20^{\star}$ & - & 1.0 & 50 & 12 & 2.770 & 0.318 & 0.705 & 1.063 \\
\hline VF501075R & 190.46 & 4.86 & 1.0 & 50 & 7.5 & 3.256 & 0.327 & 0.923 & 1.063 \\
\hline VF501030R & 219.81 & 17.57 & 1.0 & 50 & 3 & 4.981 & 0.338 & 0.954 & 1.063 \\
\hline VF500512R & 189.03 & - & 0.5 & 50 & 12 & 2.189 & 0.296 & 0.875 & 0.901 \\
\hline VF500575R & 197.30 & 4.19 & 0.5 & 50 & 7.5 & 2.564 & 0.302 & 1.023 & 0.901 \\
\hline VF500530R & 221.48 & 14.65 & 0.5 & 50 & 3 & 3.898 & 0.316 & 1.157 & 0.901 \\
\hline
\end{tabular}




\section{Experimental analysis}

The specification of the reinforced concrete beam models depended on parameters such as concrete compression strength, dimensions of the beams, category, nominal diameter and details of the reinforcement bars. Through the bibliographical revision required for the development of this research, it was verified that confinement reinforcement becomes only interesting in beams, where the risk of abrupt failure of the structural element exists due to the concrete crushing in the compression zone of the cross section. Through, also, the data supplied by the numerical analysis of item 4 , it was observed that the most relevant factor in this study of reinforced concrete beams designed with confinement reinforcement is the transverse confinement reinforcement ratio. Therefore, an experimental program was created, in which 4 over-reinforced beams were tested. These beams had strains relative to normally balanced beams and the spacing between the stirrup axles used for the beam confinement as a study parameter. Some of the tested beams were reference beams, in other words, designed without confinement reinforcement. The designed beams with confinement reinforcement are from the VC series (Confined Beams), while the beams designed in a conventional way are from the VS series (Simple Beam).

All beams had a cross section of $15 \mathrm{~cm}$ width by $30 \mathrm{~cm}$ height, beam length of $305 \mathrm{~cm}$ and effective span of $285 \mathrm{~cm}$.

Figure [2] presents the cross section and the static scheme of the tested beams. The static scheme of supported beams was adopted for its easy execution of the tests at laboratory and because it was not the predominant factor in the ductility analysis, whereby the values of the bending moments and vertical strain measured at mid-span are necessary.

\section{Table 7 - Factor analysis of ductility indexes of beams confined through square stirrups}

\begin{tabular}{|c|c|c|c|c|c|}
\hline \multicolumn{6}{|c|}{ Pre-peak ductility index } \\
\hline Variable & $\begin{array}{l}\text { Sum of the } \\
\text { square roots }\end{array}$ & $\begin{array}{l}\text { Degree of } \\
\text { freedom }\end{array}$ & $\begin{array}{l}\text { Average of the } \\
\text { square roots }\end{array}$ & $\mathrm{F}_{0}$ & $\begin{array}{c}\text { Minimum values for the } \\
\text { factor } F_{0} \text { to be relevant } \\
F_{0,01 ;: 26}-F_{0,05 ; n: 26}\end{array}$ \\
\hline$f_{c k}$ & 0.131 & 2 & 0.065 & $1650^{*}$ & $5.33-3.37$ \\
\hline$\varepsilon_{\mathrm{s}}$ & 0.04585 & 2 & 0.023 & $578.615^{\star}$ & $5.33-3.37$ \\
\hline $\mathrm{s}$ & 0.003641 & 2 & 0.00182 & $45.948^{*}$ & $5.33-3.37$ \\
\hline $\mathrm{f}_{\mathrm{ck}-\varepsilon_{\mathrm{s}}}$ & 0.018 & 4 & 0.004603 & $116.172^{*}$ & $4.11-2.74$ \\
\hline$f_{c k-s}$ & 0.000705 & 4 & 0.0001761 & 2.996 & $4.11-2.74$ \\
\hline$\varepsilon_{s-} S$ & 0.000475 & 4 & 0.000119 & $4.446^{*}$ & $4.11-2.74$ \\
\hline Erro & 0.000317 & 8 & 0.0003962 & - & - \\
\hline Total & 0.2007 & 26 & - & - & - \\
\hline \multicolumn{6}{|c|}{ Post-peak ductility index } \\
\hline Variable & $\begin{array}{l}\text { Sum of the } \\
\text { square roots }\end{array}$ & $\begin{array}{l}\text { Degree of } \\
\text { freedom }\end{array}$ & $\begin{array}{l}\text { Average of the } \\
\text { square roots }\end{array}$ & $\mathbf{F}_{0}$ & $\begin{array}{l}\text { Minimum values for the } \\
\text { factor } F_{0} \text { to be relevant } \\
F_{0,01 ; n: 26}-F_{0,05 ;: ; 26}\end{array}$ \\
\hline$f_{c k}$ & 0.045 & 2 & 0.022 & $6.626^{*}$ & $5.33-3.37$ \\
\hline$\varepsilon_{\mathrm{s}}$ & 0.041241 & 2 & 0.021 & $5.208^{*}$ & $5.33-3.37$ \\
\hline $\mathrm{s}$ & 0.302 & 2 & 0.153 & $38.548^{*}$ & $5.33-3.37$ \\
\hline$f_{c k}-\varepsilon_{s}$ & 0.028 & 4 & 0.00696 & 1.757 & $4.11-2.74$ \\
\hline$f_{c k-s}$ & 0.065 & 4 & 0.016 & 1.369 & $4.11-2.74$ \\
\hline$\varepsilon_{\mathrm{s}}-\mathrm{S}$ & 0.022 & 4 & 0.00542 & $4.13^{*}$ & $4.11-2.74$ \\
\hline Erro & 0.032 & 8 & 0.00396 & - & - \\
\hline Total & 0.538 & 26 & - & - & - \\
\hline
\end{tabular}




\section{Figure 2 - Static loads scheme and cross section of the tested beams}

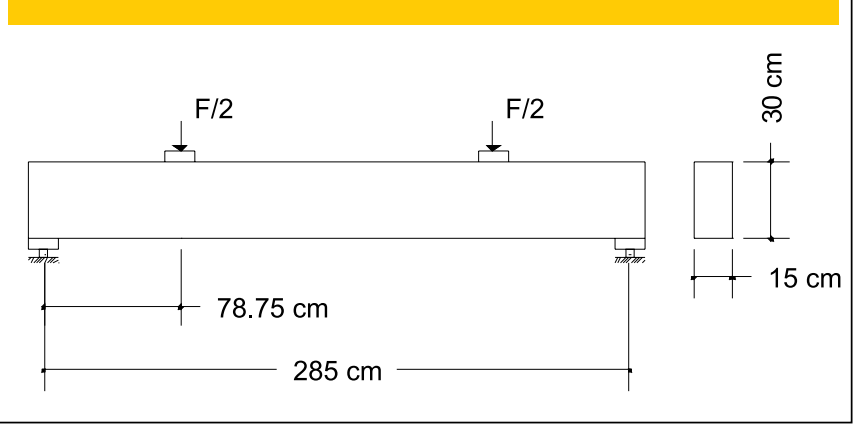

The tested beams were designed with concrete compression strain $\varepsilon_{\mathrm{c}}=3.5 \%$, tensile reinforcement strain $\varepsilon_{\mathrm{y}}=3.87 \%$ and the average concrete compression strength equal to $25 \mathrm{MPa}$. For the design of the beams the basic hypotheses recommended by the Brazilian Standard NBR 6118:2003 [10] were respected.

However, the tensile reinforcement area calculated for the beams was $8.80 \mathrm{~cm}^{2}(2 \varnothing 20 \mathrm{~mm}$ and $2 \varnothing 12.5 \mathrm{~mm}$ ), while the compression reinforcement area was $0.63 \mathrm{~cm}^{2}(2 ø 6.3 \mathrm{~mm})$. Therefore, the tensile reinforcement ratio and compression reinforcement ratio were equal to $\rho=1.96 \%$ and $\rho^{\prime}=0.14 \%$ respectively. These reinforcement areas respected the limit specified by the Brazilian Standard NBR 6118:2003 [10], which is equal to $4 \%$ of $A_{c}$, where $A_{c}$ is the cross sectional area of the beam.

The transverse confinement reinforcement was dimensioned following the recommendations of NBR 6118:2003 [10], related to the model I, in which it is allowed that the strut is inclined at $\theta=45^{\circ}$ in re- lation to longitudinal axis of the beam and $V_{c}$ (part of the shear stress resisted for complementary mechanisms the truss model idealized by Ritter e Mörsch) is presumed to be constant. Double leg closed stirrups were adopted with $8 \mathrm{~mm}$ diameter and spaced $7 \mathrm{~cm}$.

The confinement stirrups had a $5 \mathrm{~mm}$ diameter and spacing of 5 $\mathrm{cm}, 10 \mathrm{~cm}$ and $15 \mathrm{~cm}$. These stirrups were placed in the compression zone of the cross section (above the neutral axis), where only compression stresses existed. This arrangement was adopted to avoid the absorption of tensile stresses by the stirrups, therefore, increasing the confinement efficiency.

The stirrup anchorage was guaranteed through hooks with an angle of $45^{\circ}$ and length of $10 \varphi_{t}$.

The Figure [3] shows the reinforcement bar details of the tested beam.

A computerized servo-hydraulic test machine (Instron, model A1891Y-1001) was used for testing the beams, that allowed to carry out static tests with a maximum nominal load of $639 \mathrm{kN}$, having a maximum piston stroke of $150 \mathrm{~mm}$. SYSTEM 5000 of the Measurements Group was used for the data collection system of stress, strain and displacement values supplied, respectively, by the servo-hydraulic test machine, transducers and extensometers.

One aim of the tests was to analyze the beam ductility. Therefore, it was necessary to know the behavior of the descending branch of the load vs. displacement curve. This was only possible with the use of the servo-hydraulic test machine, where, through the piston, displacements were applied instead of loads. The load speed for all the tested beams started at $0.010 \mathrm{~mm} / \mathrm{s}$ until the appearance of the first crack. After its occurrence, the speed was increased to $0.020 \mathrm{~mm} / \mathrm{s}$, maintaining this speed until the end of the test.

The use of a metallic beam placed on the beams was necessary, so that two load application points were obtained, see Figure [4]. The metallic beam constituted by two I steel profiles of

\section{Figure 3a-Beam VC-01}

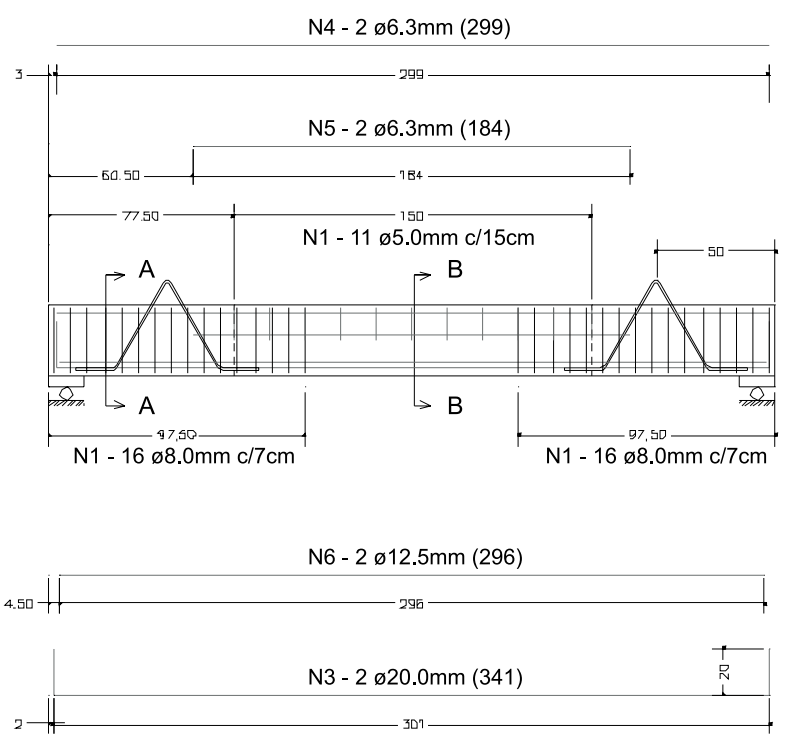

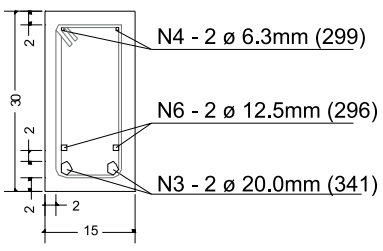

Section A-A

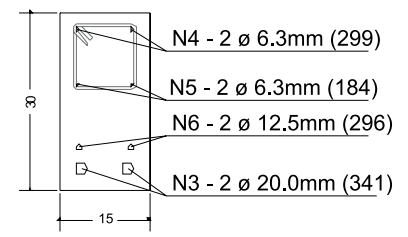

Section B-B

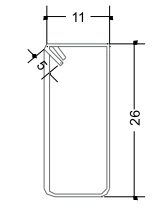

$\mathrm{N} 1-32$ ø $8.0 \mathrm{~mm}$ $\mathrm{c} / 7 \mathrm{~cm}(84 \mathrm{~cm})$

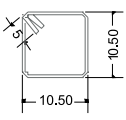

$\mathrm{N} 2-11 ø 5.0 \mathrm{~mm}$ c/ $15 \mathrm{~cm}(52 \mathrm{~cm})$ 
$254 \mathrm{~mm}$ and web thickness of $7.9 \mathrm{~mm}$, could support a load of $300 \mathrm{kN}$ applied at mid span. The profiles were made of A-36 steel with yield strength of $250 \mathrm{MPa}$. The metallic beam was supported on steel plates of $150 \mathrm{~mm} \times 100 \mathrm{~mm} \times 15 \mathrm{~mm}$ with a theoretical span of $127.5 \mathrm{~cm}$.
The plan dimensions of the supporting steel plates were $150 \mathrm{~mm} \mathrm{x}$ $100 \mathrm{~mm}$. These dimensions were chosen to avoid concrete crushing in the contact area of supporting plates with the beams. The same procedure was adopted for steel plates used in the two load application points. For a better stress distribution in the beam close

\section{Figure 3b - Beam VC-02}

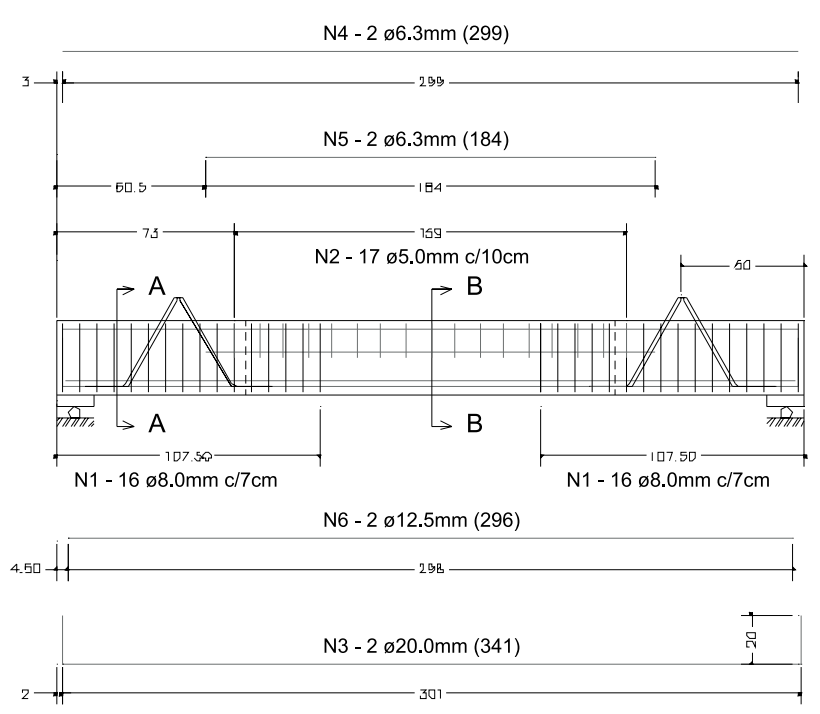

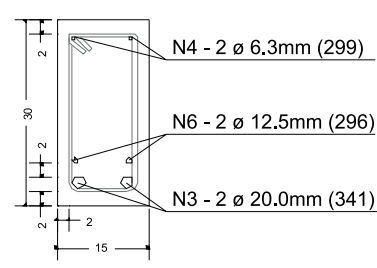

Section A-A

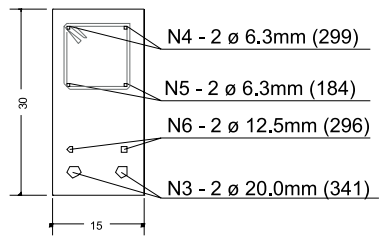

\section{Section B-B \\ Section B-B}

\section{Figure 3c - Beam VC-03}

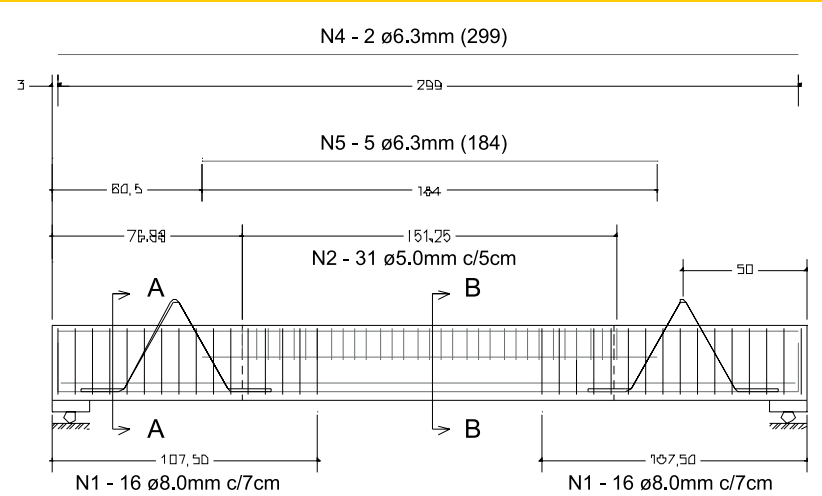

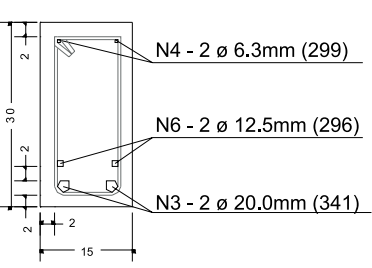

\section{Section A-A}

N6 - $2 ø 12,5 \mathrm{~mm}(296)$
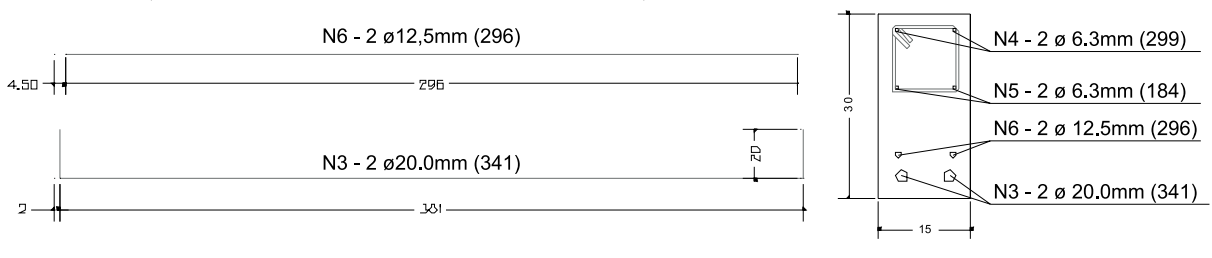

$\mathrm{N} 2-17 ø 5.0 \mathrm{~mm}$

$\mathrm{c} / 10 \mathrm{~cm}(52 \mathrm{~cm})$

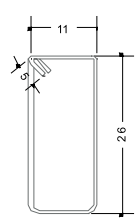

$\mathrm{N} 1-32 ø 8.0 \mathrm{~mm}$ $\mathrm{c} / 7 \mathrm{~cm}(84 \mathrm{~cm})$

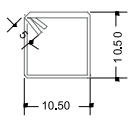

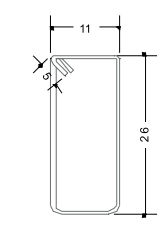

$\mathrm{N} 1-36 ø 8.0 \mathrm{~mm}$ $\mathrm{c} / 7 \mathrm{~cm}(84 \mathrm{~cm})$

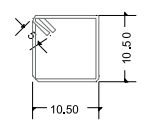

N2 - $31 ø 5.0 \mathrm{~mm}$ $\mathrm{c} / 5 \mathrm{~cm}(52 \mathrm{~cm})$

\section{Section B-B}


Figure 3d - BeamdVS-01
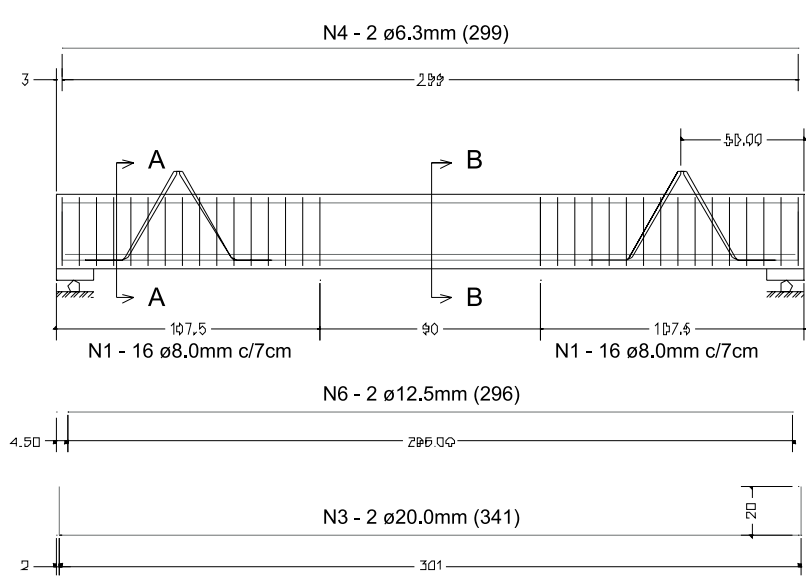
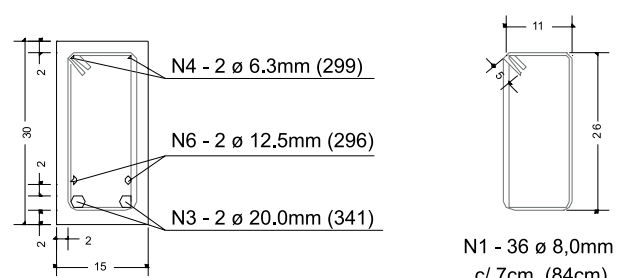

$\mathrm{N} 1-36 ø 8,0 \mathrm{~mm}$ $\mathrm{c} / 7 \mathrm{~cm}(84 \mathrm{~cm})$

\section{Section A-A}

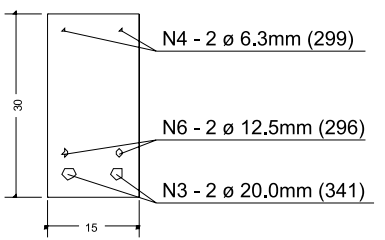

Section B-B

to the two load application points, wet sand was placed under each plate with an average sand thickness of $5 \mathrm{~mm}$. Figure [4] shows the test scheme of the beams.

Table [8] shows the general properties of tested beams, results of concrete compression strength $\left(f_{c}\right)$, results of the concrete longitudinal module $\left(E_{c}\right)$ and results of confinement parameters as compression strength of the confined $\left(f_{c c}\right)$, strain of the confined concrete $\left(\varepsilon_{c}\right)$ and strain of the confined concrete related to $85 \%$ of the ultimate stress.

In Figures 5 and 6, the ductility increase can be observed with the volumetric ratio increase of the confinement reinforcement, in other words, the ductility index increases as the spacing between stirrups decreases, because the volumetric ratio of the confinement reinforcement is inversely proportional to the spacing between stirrups intended for confinement. For the unconfined beam, beam VS-01, the volumetric ratio of the confinement reinforcement is equal to zero, therefore the spacing between stirrups tends to the infinite.
The increase of the post-peak ductility index due to the increase of the transverse confinement ratio can be verified in Table [9] where the ductility indexes of each tested beam are presented.

In figure [5] and [6] it is also possible to verify that there was no increase of the flexural strength capacity of the confined beams compared to the unconfined beam, in other words, it was not observed significant increase in the flexural strength capacity of the beams due to the increase of the transverse confinement ratio. Figures [7] and [8] illustrate the variations of the ID $D_{\text {postt }}$ vs. $\rho_{\text {sw.cont }}$ and $I D_{\text {post }}$ Vs. $S$ of the VC-01, VC-02, VC-03 and VS- 01 beams. The first relation was obtained through non-linear regression of the experimental values, while the second relation was obtained through linear regression of the same values.

In the curves of the Figures [5] and [6] it is verified, more clearly, the increase of post-peak ductility index with the increase of the volumetric ratio of the transverse confinement reinforcement and spacing decrease between stirrups used for confinement. A nonlin-

\section{Figure 4 - Test scheme of the beams}
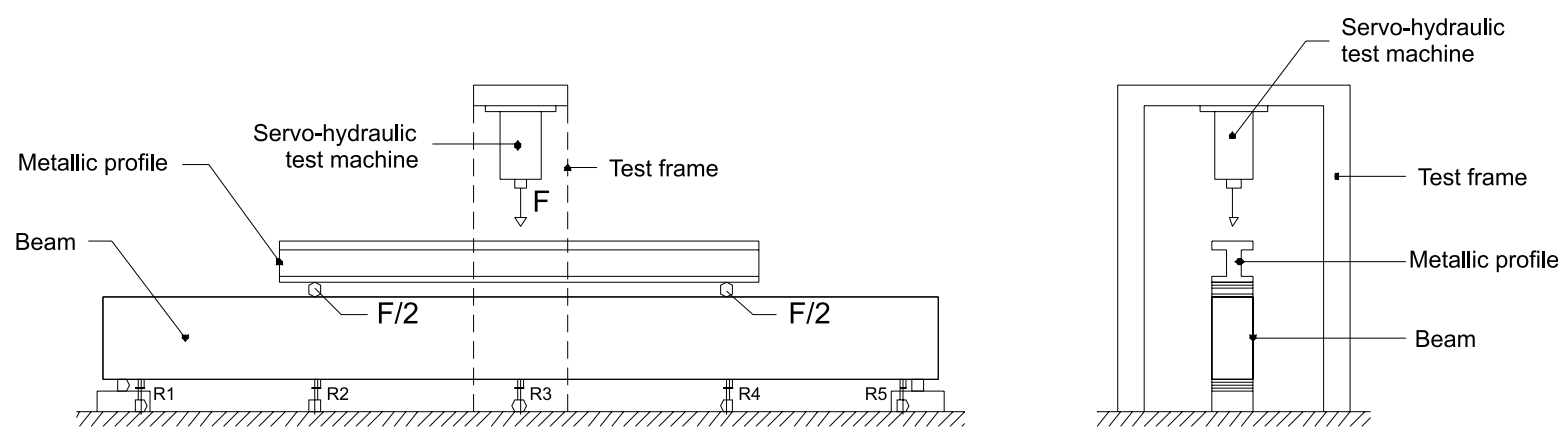


\section{Table 8 - General properties of the tested beams}

\begin{tabular}{|c|c|c|c|c|c|c|c|c|c|c|c|c|}
\hline \multirow[b]{2}{*}{ BEAMS } & \multirow[b]{2}{*}{$\begin{array}{c}b_{w} \\
(\mathrm{~cm})\end{array}$} & \multirow[b]{2}{*}{$\begin{array}{c}\mathrm{h} \\
(\mathrm{cm})\end{array}$} & \multirow[b]{2}{*}{$\begin{array}{c}d \\
(\mathrm{~cm})\end{array}$} & \multicolumn{3}{|c|}{$A_{\text {sw,cont. }}$} & \multirow[b]{2}{*}{$\begin{array}{c}f_{c} \\
(\mathrm{MPa})\end{array}$} & \multirow[b]{2}{*}{$\begin{array}{c}\varepsilon_{\mathrm{s}} \\
(\% \circ)\end{array}$} & \multirow[b]{2}{*}{$\begin{array}{c}E_{c} \\
(G P a)\end{array}$} & \multicolumn{3}{|c|}{ Confinement } \\
\hline & & & & $\begin{array}{l}\text { hc } \\
(\mathrm{cm})\end{array}$ & $\begin{array}{c}\mathrm{s} \\
(\mathrm{cm})\end{array}$ & $\begin{array}{c}\emptyset \\
(\mathrm{mm})\end{array}$ & & & & $\begin{array}{c}\mathrm{f}_{\mathrm{cc}} \\
(\mathrm{MPa})\end{array}$ & $\begin{array}{c}\varepsilon_{\mathrm{c}} \\
(\% \circ)\end{array}$ & $\begin{array}{c}\varepsilon_{\mathrm{c85}} \\
(\% \circ)\end{array}$ \\
\hline VC-01 & 15 & 30 & 27 & 10.5 & 15 & 5 & 23.47 & 3.87 & 26.7 & 25.23 & 3.258 & 7.496 \\
\hline VC-02 & 15 & 30 & 27 & 10.5 & 10 & 5 & 26.01 & 3.87 & 27.2 & 28.45 & 3.865 & 10.82 \\
\hline VC-03 & 15 & 30 & 27 & 10.5 & 5 & 5 & 26.96 & 3.87 & 28.2 & 30.36 & 4.617 & 16.37 \\
\hline VS-01 & 15 & 30 & 27 & - & - & - & 31.32 & 3.87 & 32.3 & - & - & - \\
\hline
\end{tabular}

Table 9 - Ductility index of the tested beams

\begin{tabular}{|c|c|c|c|c|c|c|c|c|}
\hline Beams & $\begin{array}{l}F_{\text {max }} \\
(k N)\end{array}$ & $\begin{array}{c}f_{c} \\
(M P a)\end{array}$ & $\begin{array}{c}\mathrm{s} \\
(\mathrm{cm})\end{array}$ & $\begin{array}{c}\rho_{\text {sw, conf }} \\
(\%)\end{array}$ & $\begin{array}{c}\delta_{\mathrm{co}} \\
(\mathrm{cm})\end{array}$ & ID pre & $I_{\text {post }}$ & $I_{\text {elast }}$ \\
\hline VS-01 & 266.75 & 31.32 & $\infty$ & 0 & 2.869 & 0.285 & 0 & 0.371 \\
\hline VC-01 & 259.01 & 23.47 & 15 & 1.057 & 2.974 & 0.312 & 0.651 & 0.347 \\
\hline VC-02 & 252.36 & 26.01 & 10 & 1.585 & 2.757 & 0.24 & 0.721 & 0.365 \\
\hline VC-03 & 267.61 & 26.96 & 5 & 3.17 & 2.858 & 0.235 & 0.878 & 0.396 \\
\hline
\end{tabular}

ear regression was carried out with the values of Table [9] to obtain an equation that expresses the post-peak ductility index. The correlation coefficient $\mathrm{R}^{2}$ obtained from the nonlinear regression was $98.61 \%$. Equation [3] shows the post-peak ductility index obtained with the experimental values.

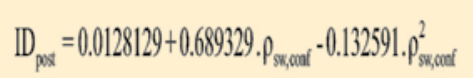

Where $\rho_{\text {sw,conf }}$ is the volumetric ratio of the transverse confinement reinforcement, expressed in \%.

All the ductility indexes of the tested beams did not reach the ideal ductility index of 0.905 given in item $4\left(I_{\text {postt,ideal }}=0.905\right)$. However, beam VC-03 with a highest volumetric ratio of the confinement reinforcement had a post-peak ductility index equal to 0.878 , very close to the ideal ductility index, therefore, considered ductile.

Based on analysis of the pre-peak ductility index, $I D_{\text {pre }}$, it was concluded that the results varied randomly not depending on the volumetric ratio of the transverse confinement reinforcement. This was already expected, because according to the numerical analysis developed in item 4 , the predominant factor of the pre-peak ductility index for beams confined through square stirrups is the concrete compression strength, followed by tensile reinforcement strain and finally the spacing between confinement stirrups.
According to the methodology developed by Lima Júnior \& Giongo [6], for a hypothetical beam with perfect elastoplastic behavior, the pre-peak ductility index would be equal to 0.5 , while the post-peak ductility index would be equal to 1 . Observing Figure [7], it is noticed that the post-peak ductility index tends to 1.0 , therefore complying with the methodology developed by the researchers as mentioned above.

Besides the influence of volumetric ratio of the transverse confinement reinforcement on beam ductility as shown previously, there is also a direct influence on the compression strength of the confined concrete, in other words, the higher the volumetric ratio of the transverse confinement reinforcement, the higher the compression strength of the confined concrete. Through the tests of beams VC-01, VC-02, VC-03 and VS-01, it was possible to observe this behavior. In Figure [9] the influence of the volumetric ratio of transverse confinement reinforcement could be verified on the compression strength of the confined concrete.

Carrying out a nonlinear regression of the curve in Figure [9], an expression was obtained that represents the confined concrete compression strength in function of the unconfined concrete strength and the volumetric ratio of the transverse confinement reinforcement, Equation [4]. The relations between the strength of the confined concrete and unconfined concrete used to describe the curve of Figure [9] were obtained through the arithmetic mean of the confined concrete compression strengths of each layer of the confined concrete core in relation to the unconfined concrete compression strength. 


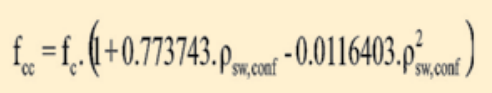

The correlation coefficient $R^{2}$ of Equation [4] is $99 \%$ and the compression strengths of the confined and unconfined concrete are expressed in megapascals.

\section{Conclusion}

The numerical model provided consistent results when compared with the results of experimental models, presenting good approximation.

In relation to the ductility of the beams, it was observed that, with the increase of volumetric ratio of transverse confinement ratio, there was an increase of the post-peak ductility index. The ductility evaluation criterion proposed by Lima Júnior \& Giongo [6], gave a reasonable idea regarding the ductility, presented by the beams.

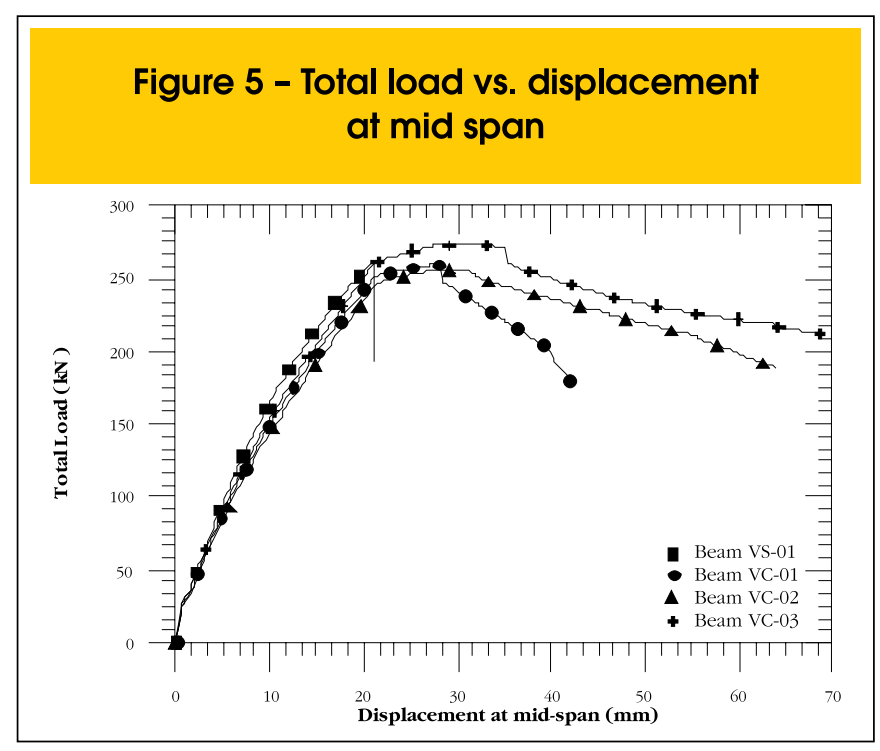

Figure 6 - Load at the load application point vs. displacement at the load application point

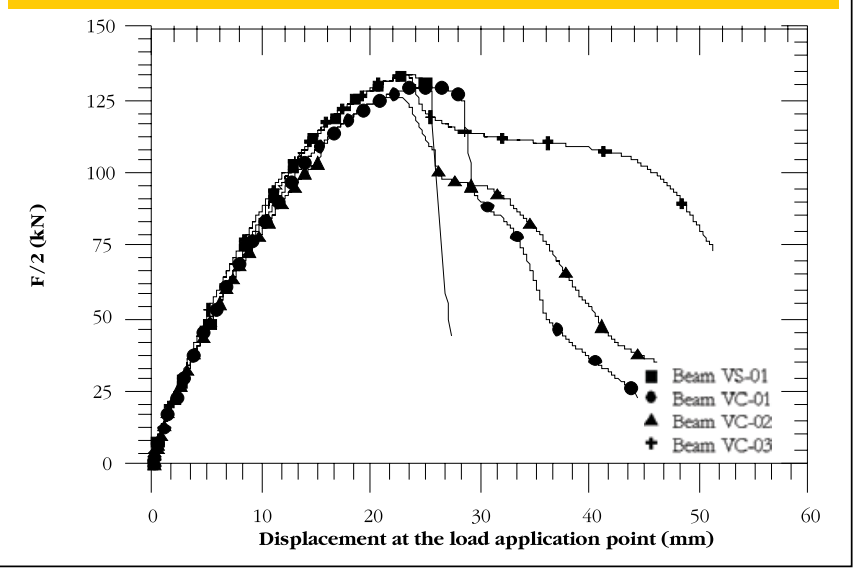

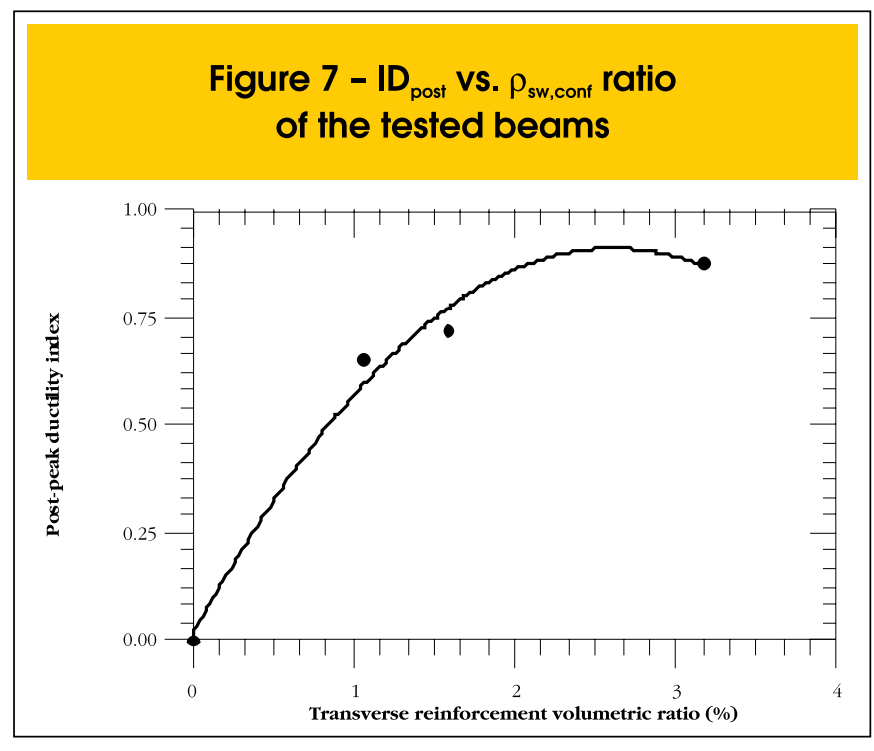

Figure 8 - ID post $v s$. $\mathbf{s}$ ratio of the tested beams

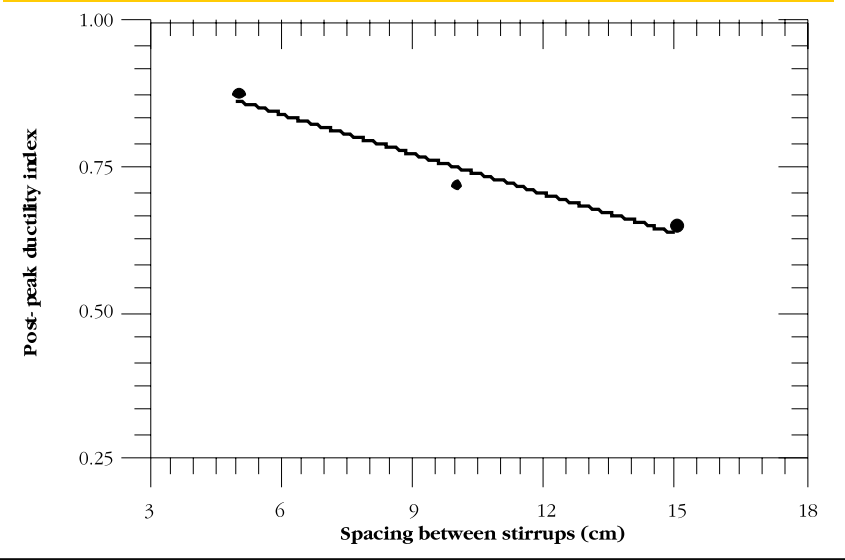

Therefore it was demonstrated that in the post-peak, the behavior of the structural elements tended to the plastic-perfect model.

The analysis of the pre-peak ductility index, $I D_{\text {pre }}$, showed that the results of these indexes varied randomly, not depending, therefore, on volumetric ratio of the transverse confinement reinforcement. This was already expected, because based on the results of the numerical analysis developed in item 4, it is noticed that for beams confined through square stirrups, the factors that influence this index are: concrete compression strength followed by the tensile reinforcement strain and at last the volumetric ratio of the transverse confinement reinforcement, enabling to disregard this last variable.

The confinement reinforcement, besides increasing the ductility of the structural elements, also increases the concrete compression strength within the confined concrete core, whereas this increase is proportional to the increase of volumetric ratio of the confinement reinforcement.

The compression strength of the confined concrete core has in- 


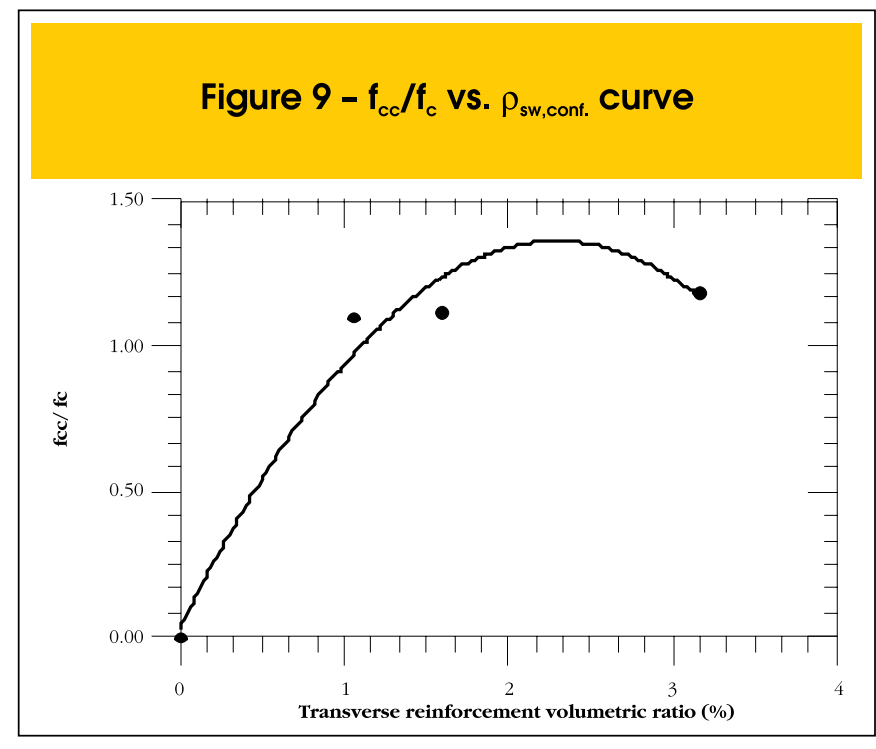

creased by an average of $13 \%$. This increase was not enough to increase the flexural strength capacity of the beams.

The compression strength of the confined concrete core decreases with the proximity of the neutral axis, because the effective lateral confinement stresses also decrease with the proximity of the neutral axis.

\section{Acknowledgements}

To FAPESP (State of São Paulo Research Foundation) for the present (2007) financial support. To CAPES (Brazilian Bureau of Professional Betterment) for financial support to first author in development of Master Degree (2002). To the assistant professor Humberto Correia Lima Júnior, Federal University of Pernambuco at Caruarú - Brazil, for the contribution concerning the numerical analysis.

\section{References}

[01] Base, G. D. Helical reinforcement in the compression zone of concrete beams. Constructional \& Engineering, 1962, p. 456-460, December.

[02] Base, G. D. \& Read, J. B. Effectiveness of helical binding in the compression zone of concrete beams. Journal of The American Concrete Institute, Title, n. 62-47, 1965, p. 763-780, July.

[03] Nawy, E. G., Danesi, R. F., Grosko, J. J. Retangular spiral binders effect on plastic hinge rotation capacity in reinforced concrete beams. $\mathrm{ACl}$ Journal, Title n. 65-67, 1968, p. 1001-1010, December.

[04] Ziara, M. M., Haldane, D., Kuttab, A. S. Flexural behavior of beams with confinement. ACl Journal, 1995, Title n. 92-S11, pg. 103-114, January-February.

[05] Krüger, S. D. Uma metodologia para a análise de porticos planos de concreto armado sujeitos a grandes deslocamentos. Dissertação (Mestrado) Departamento de Engenharia Civil PUC/Rio, 1990.

[06] Lima Júnior, H. C. \& Giongo, J. S. Avaliação da ductilidade do concreto de alta resistência reforçado com fibra de aço. Anais do $43^{\circ}$ Congresso Brasileiro do Concreto, Foz do Iguaçu, Paraná, 2001.

[07] Saatcioglu, M. \& Razvi, S. R. Strengath and ductility of confined concrete. ASCE Jounarl of Structural Engineering, v. 118, n. 6, 1992, p. 1590-1607, June.

[08] Lima Júnior, H. C. \& Giongo, J. S. Fator de ductilidade para pilares de concreto de alta resistência. Engenharia, Estudo e Pesquisa, 2000, v. 3, n. 2, Julho-Dezembro.

[09] Delalibera, R. G.. Análise teórica e experimental de vigas de concreto armado com armadura de confinamento. Dissertação (mestrado). Escola de Engenharia de São Carlos, Universidade de São Paulo. São Carlos, 2002.

[10] ASSOCIAÇÃO BRASILEIRA DE NORMAS TÉCNICAS (ABNT) Projeto de estruturas de concreto: NBR 6118:2003. Rio de Janeiro, ABNT, 2004.

[11] Lima júnior, H. C. \& Giongo, J. S. Modelo teórico para análise de pilares de concreto de alta resistência com confinamento lateral. Engenharia, Estudo e Pesquisa, 2000, v. 3, n. 2, Julho-Dezembro.

[12] ASSOCIAÇÃO BRASILEIRA DE NORMAS TÉCNICAS (ABNT) Barras e fios de aço destinados a armaduras para concreto armado. NBR 7480:1996. sRio de Janeiro, ABNT, 1996. 